\title{
Teknik pembuatan tepung tulang ikan tuna pada Kegiatan Pengabdian PPUPIK Rumah Ikan
}

\author{
Umar Tangke ${ }^{1}$, Aisyah Bafagih ${ }^{2}$, Ruslan A. Daeng ${ }^{3}$ \\ ${ }^{1,2,3}$ Universitas Muhammadiyah Maluku Utara
}

\begin{abstract}
This fish bone waste is realized by the university as an important and potential material to be de ve loped into something that is beneficial to the body because it contains various important substances for the needs of the human body including ca lcium, where calcium is a essential nutrient in various bodily functions, one of which a s nutrients to grow and support the development of motor functions to be more optimal and develop well. The re su lts of the activity obtained tuna bone waste a fter going through several processes and innovations, becoming a product that is beneficial to the body. As has been done in the PPUPIKHouse offish activities where the wa ste that had been a source of pollution in both form and odor has become a useful product to increase the value of calcium and a good source of calcium to be added as a fortification ingredient in the processed products of PPUPIK R u mah I kan namely tuna kering kayu and tuna rica-rica.
\end{abstract}

Key words: calcium, fish bone flour, yellowfin, woody tuna

\section{PENDAhuluan}

Limbah tulang ikan dari tahun ke tahun terus mengalami peningkatan sehingga akan memberikan dampak yang kurang baik, baik dari jumlah sampai bau busuk yang di timbulkan oleh keberadaan limbah tersebut. Limbah tulang ikan ini disadari oleh pihak perguruan tinggi sebagai bahan penting dan potensil untuk di kembangkan menjadi sesuatu yang bermanfaat bagi manusia karena dalam limbah tersebut terkandung berbag ai zat penting bagi kebutuhan tubuh manusia, diantaranya kalsium. Tulang ikan merupakan limbah yang memiliki kandungan kalsium yang sangat tinggi dan juga mengandung sel-sel hidup dan matrik intraseluler dalam bentuk garam mineral, dinataranya kalsium fosfat, kalsium karbonat dan magnesium fosfat (Gobinathan et al., 2009). Adapun pemanfaatan tulang ikan ini dapat dilakukan melalui proses pengolahan tulang ikan menjadi tepung. Secara komposisi proksimat dengan menguji kandungan gizi pada tepung tulang ikan tuna didapatkan kadar air $11.34 \%$, bu $59.49 \%$, protein $23.86 \%$, lemak $0.96 \%$, karbohidrat $4.35 \%$ dan kalsium $17.47 \%$ (Harris et al,. 1989; Kaya et al, 2008; Talib et al, 2014).

Kalsium merupakan salah satu nutrien esensial yang sangat dibutuhkan untuk berbagai fungsi tubuh (Gobinathan et al., 2009). Salah satu fungsi kalsium bagi tubuh adalah sebagai nutrisi untuk tumbuh, menunjang perkembangan fungsi motorik agar lebih optimal dan berkembang dengan baik. Orang dewasa memerlukan kasium sebanyak 800 $\mathrm{mg} /$ hari. Kekurangan kalsium pada masa pertumbuhan dapat menyebabkan gangguan pertumbuhan tulang, osteoporosis, dan osteomalasia (Nieves, 2005; Linder, 2006; Malde et al., 2010). Melihat fenomena yang terjadi baik dari dampak maupun manfaat dari limabh tulang ikan khuusny a ikan madidihang, maka timbul ide melalui kegiatan PPUPIK Rumah Ikan untuk memanfaatkan limbah tulang ikan khususnya tulang ikan madidihang yang tadinya tidak berharga menjadi lebih bernilai dengan teknologi dan pengolahan yang sederhana yang tidak menimbulan efek negatif terhadap lingkungan.

\section{METODE KERJA}

Metode kerja pada kegiatan pembuatan tepung tulang ikan dimulai dari penyiapan bahan baku, proes pembuatan tepung tulang ikan tuna dan hasil atau produk. Tahapa dalam metode kerja untuk pembuatan tepung tulang ikan pada PPUPIK Ruah ikan dapat di lihat pada bagan alir di Gambar 1 (Tangke et al., 2018). 


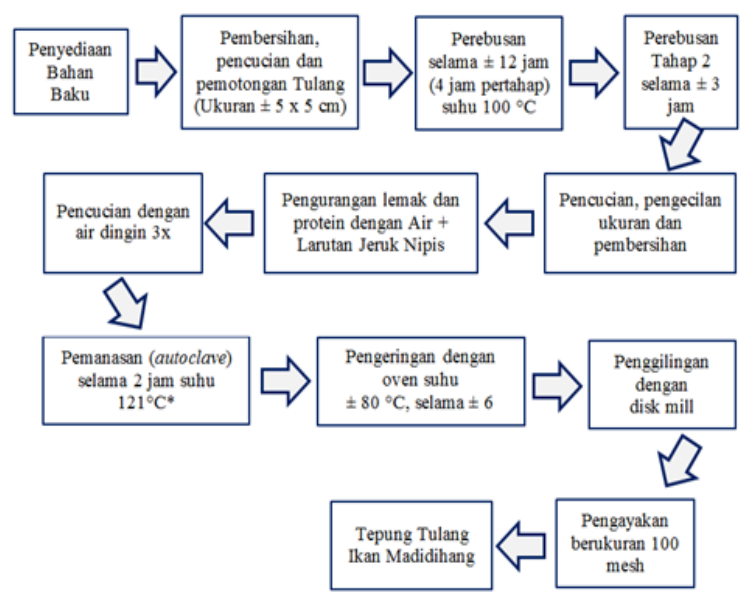

Gambar 1. Diagram alir proses pembuatan tepung tulang ikan tuna

\section{PELAKSANAAN DAN HASIL KEGIATAN}

\section{A. Penyiapan Bahan Baku}

Bahan baku yang digunakan dalam proses pembuatan tepung tulang ikan tuna terdiri dari bahan utama yakni limbah tulang ikan madidihang dan bahan tambahan yaitu jeruk nipis (Gambar 2). Pada tahap ini proses yang dilakukan adalah penyediaan bahan bahan baku sampai pada proses pembersihan limbah tulang ikan dari kotoran dan darah yang masih menempel dan selanjutnya limbah tulang tersebut dipotong dengan ukran ratarata $5 \times 5 \mathrm{~cm}$. Tahap selanjutnya proses pembuatan tepung tulang ikan tuna yang dimulai dari proses perebusan tahap 1 .

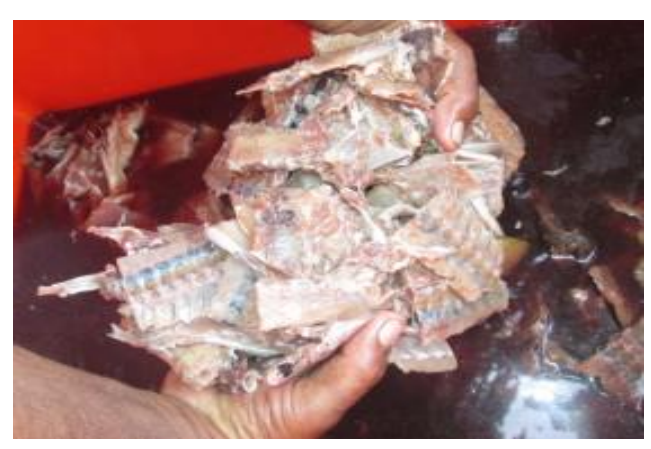

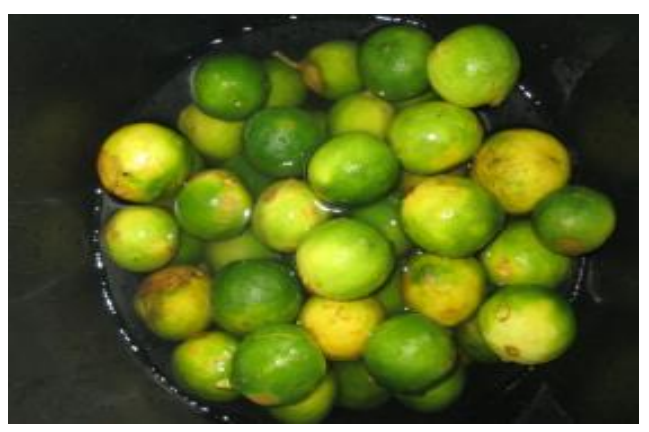

Gambar 2. Bahan baku (limbah tulang ikan dan jeruk nipis)

\section{B. Proses Pembuatan Tepung Tulang Ikan Tuna}

Proses pembuatan tepung tulang ikan tuna di mulai dari proses perebusan awal (Gambar 3) selama kurang lebih 12 jam yang terbagi dalam 3 tahap dengan waktu perebusan masing-masing adalah 4 jam. Perlakuan perebusan ini bertujuan untuk melepaskan sisa-sisa daging ikan tuna yang masih menepel pada tulang ikan, sehingga tulang ikan benar-benar bersih. Tulang ikan yang telah bersih Gambar 4) selanjutnya di potong lebih kecil dengan ukuran 1-2 cm dan selanjutnya akan dilakukan perebusan tahap 2 .

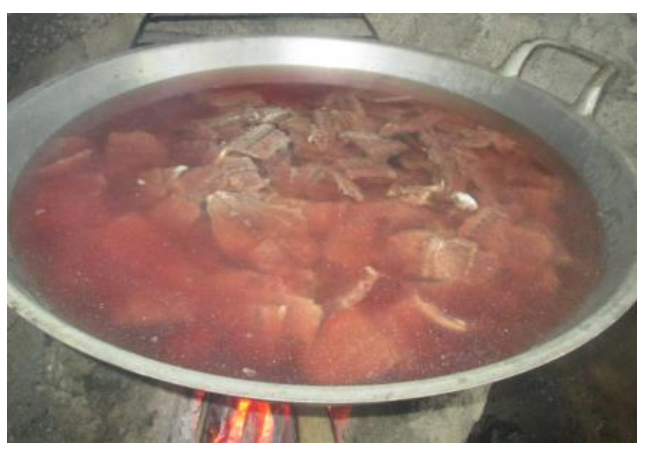

Gambar 3. Proses perebusan tahap 1

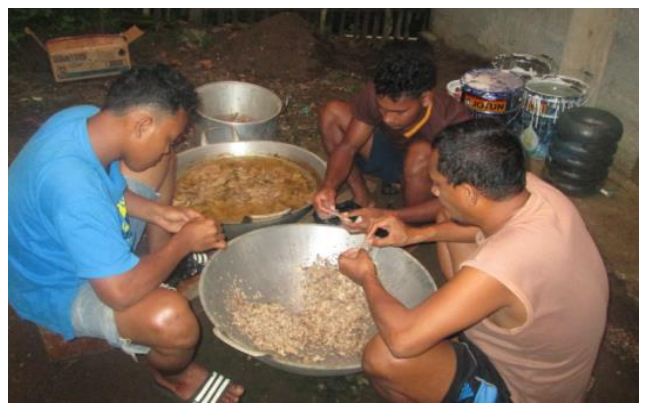

Gambar 4. Proses pembersihan tulang dari sisa dging yang masih menempel 
Proses perebusan tahap 2 dilakukan selama 3 jam, dengan wadah kaca (Gambar 4.) yang bertujuan untuk menghilangkan kadar lemak dan protein pada tulang ikan, karena diketahui bahwa pada tulang ikan juga banyak mengandung lemak dan protein sehingga perlu dihilangkan untuk mendapatkan tulang yang bebas lemak dan protein. Pada proses ini, perebusan dilakukan menggunakan larutan jeruk nipis sebagai katalisator.

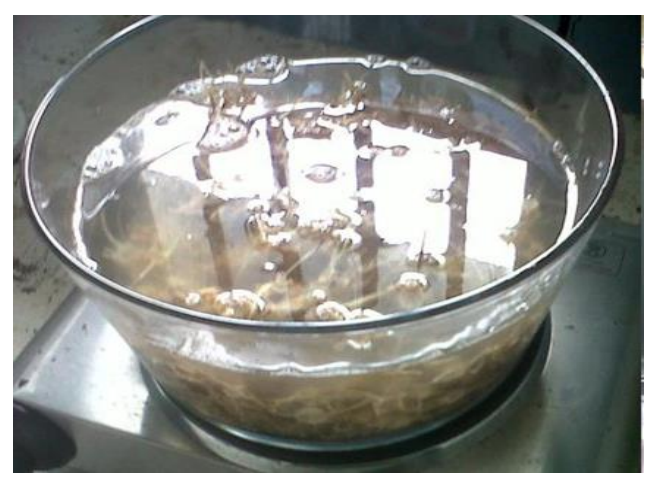

Gambar 5. Proses perebusan tahap 2

Tahap selanjutnya adalah tulang di panaskan dengan menggunakan autoclave (Gambar 6) pada suhu $121^{\circ} \mathrm{C}$ selama kurang lebih 2 jam, dengan tujuan untuk menjadikan tulang streril serta meremukan tulng agar mudah dalam proses penggilingan.
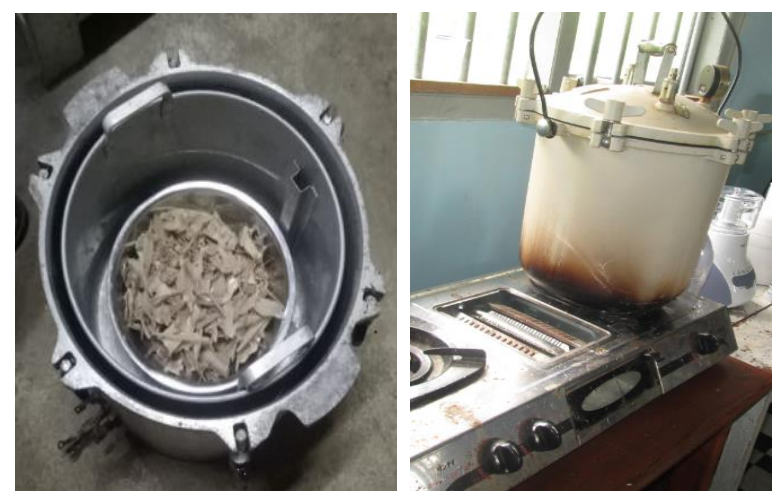

Gambar 6. Proses autoclave

Tahap selanjutnya adalah proses pengeringan tulang pada oven selama 12 jam pada suhu $80^{\circ} \mathrm{C}$ (Gambar 7), perlakuan ini bertujuan untuk menghasilkan tulang yang steril dan benar-benar kering sehingga mudah untuk di lakukan proses penghalusan atau penggilingan.

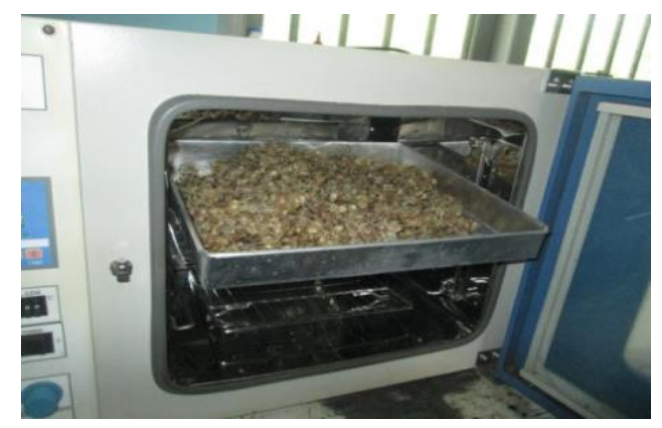

Gambar 7. Proses pengeringan dengan oven

Proses selanjutnya setelah pengeringan tulang adalah proses selanjutnya adalah penggilingan dan pengayakan. Untuk mendapatkan tepung tulang yang baik maka proses penggilingan dilakukan dengan menggunakan mesin pengiling fomaks selam kurang lebih 2 menit pada putaran $2500 \mathrm{rpm}$ (Gambar 8). Selanjutnya hasil gilingan di ayak meggunakan ayakan ukuran 100 mesh (Gambar 9), untuk mendapatkan tepung dengan ukuran partikel $149 \mu \mathrm{m}$.

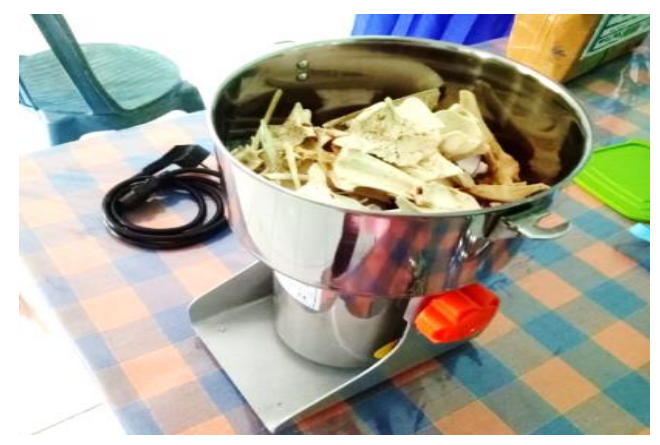

Gambar 8. Mesin penggilin fomaks

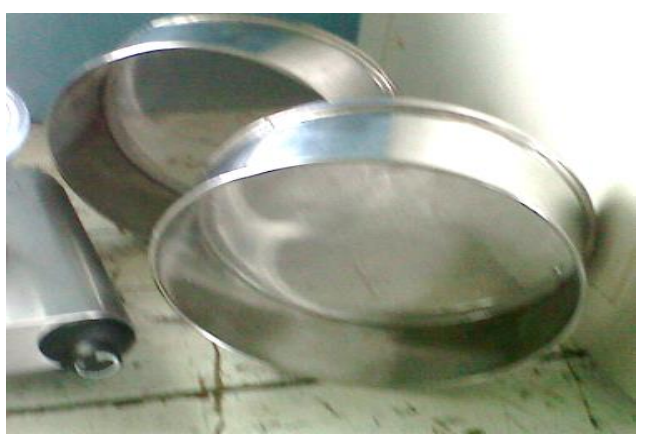

Gambar 9. Ayakan ukuran 100 mesh

\section{Hasil/Produk Tepung Tulang Ikan Tuna}

Hasil akhir tepung tulang ikan tuna dihar apkan memiliki karakteritis yang baik untuk bahan fortifikasi pada pembuatan produk ikan tuna kering 
kayu dan ikan tuna rica-rica. Hasil uji karakteristik tepung tulang ikan tuna (Gambar 10) dapat dilihat pada Tabel 1.

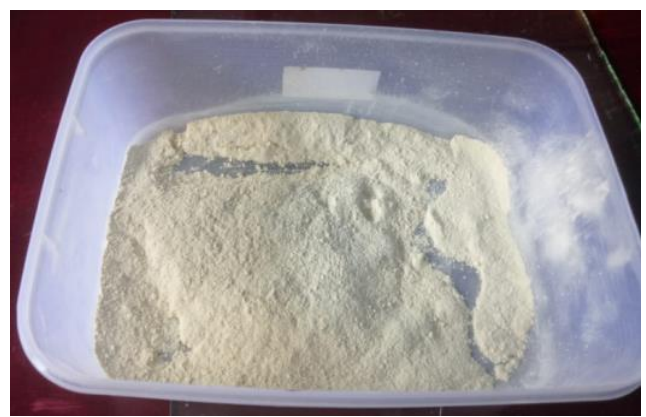

Gambar 10. Tepung tulang ikan madidihang

Tabel 1. Karakteristik Tepung Tulang Ikan Tuna

\begin{tabular}{clcc}
\hline No & $\begin{array}{c}\text { Karateristik } \\
\text { Fisik/Kimia }\end{array}$ & Nilai & Satuan \\
\hline 1 & Densitas Kamba & 1.3 & $\mathrm{~g} / \mathrm{ml}$ \\
2 & Derajat Putih & 89,2 & $\%$ \\
3 & Daya Serap Air & 98,2 & $\%$ \\
4 & $\mathrm{Ca}$ & 34,12 & $\mathrm{mg} / \mathrm{g}$ \\
5 & $\mathrm{P}$ & 0,81 & $\mathrm{mg} / \mathrm{g}$ \\
6 & $\mathrm{Mg}$ & 0,42 & $\mathrm{mg} / \mathrm{g}$ \\
7 & $\mathrm{Na}$ & 1,89 & $\mathrm{mg} / \mathrm{g}$ \\
8 & Vitamin D & 4,5 & $\mathrm{mg} / \mathrm{g}$ \\
\hline
\end{tabular}

\section{KESIMPULAN}

Limbah tulang ikan tuna setelah melalui beberapa proses dan inovasi, maka akan menjadi produk yang bermanfaat bagi tubuh. Seperti yang telah di lakukan pada kegiatan PPUPIK Rumah ikan dimana limbah yang tadinya menjadi sumber pencemaran baik dari bentuk dan bau telah menjadi produk yang bermanfaat untuk meningkatkan nilai kalsium dan sumber kalsium yang baik untuk ditambahkan sebagai bahan fortifikasi pada produk olahan PPUPIK Rumah ikan yakni ikan tuna kering kayu dan ikan tuna rica-rica.

\section{UCAPAN TERIMA KASIH}

Ucapan terima kasih disampaikan kepada Direktorat Jendral Pendidikan Tinggi yang telah memberikan dana hibah pengabdian PPUPIK kepada tim pelaksana, serta kepada Rektor Kepala LP3M dan Dekan Fakultas Pertanian Uiversitas Muhamadiyah Maluku Utara atas arahan dan pembinaanya selama proses kegiatan Pengabdian Masyarakat berlangsung.

\section{DAFTAR PUSTAKA}

Gobinathan P, Murali PV, Panneerselvam R, 2009. Interactive Effects of Calcium Chloride on Salinity-Induced Proline Metabolism in Pennisetum typoidies. Advances in Biological Research 3(5-6):168-173.

Harris SR, Karnas E. 1989. Evaluasi Gizi pada Pengolahan Bahan Pangan. Edisi kedua. Penerjemah : Achmadi S, Niksolihin S. Nutritional Evaluation of Food Process ing. Bandung: Institut Teknologi Bandung.

Kaya A, Santoso, Salamah. 2008. Utilization of catfish (Pangasius sp.) bone flour as calcium and phosphor sources in biscuit manufacturing. Master Thesis. Bogor: Graduate Program, Bogor Agricultural University.

Linder MC. 2006. Nutritional Biochemistry and Metabolis m. Penerjemah : Parakkasi A. Jakarta: UI Press.

Malde, Graff, Rasi, Vena“ la“ inen, Julshamn, Pedersen and Valaja, 2010. Fish bones- a highly available calcium source for growing pigs. Journal of Animal Physiology and Animal Nutrition.

Nieves J. W, 2005. Osteoporosis: the role of micronutrient. The American Journal of Clinical Nutrition 81:1232-1239.

Talib A., Amalan Tomia., Umar Tangke. 2014. Pemanfa atan Tepung Tulang Ikan Cakalang (Katsuwonus pelamis L) Dengan Perebusan Naoh Pada Model Tikus Ovariekto mi . Laporan Penelitian Hibah Bersaing DRPM DIKTI .

Tangke U., Aisyah Bafagih., Ruslan A. Daeng. 2018. Teknik Pengolahan dan Pengalengan Ikan Rica-Rica Pada Program PPUPIK Rumah Ikan Program Studi Teknologi Hasil Perikanan Fakultas Pertanian UMMU Ternate, Jurnal Pengamas Unkhair, Volume 1 Nomor 1, hal 32-38. 